\title{
En 2020
}

\section{Concurso de}

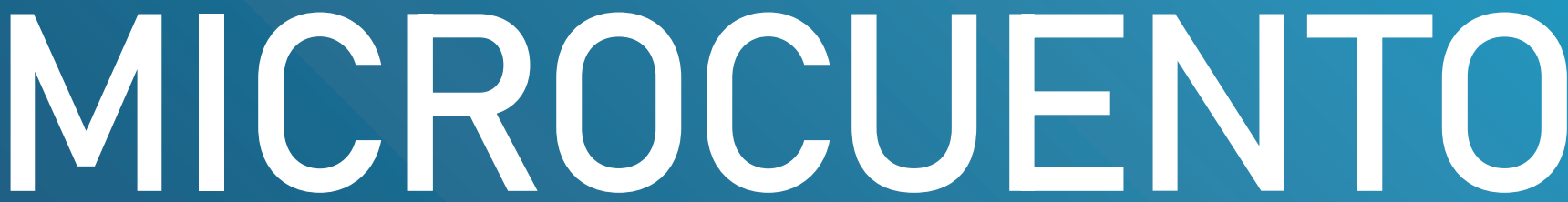

\section{sobre ciencia}

Para:

Docentes y estudiantes de UNITEC CEUTEC INNOVATEC

PARA MÁS INFORMACIÓN:

investigacion@unitec.edu fernando.escobar@unitec.edu.hn 